\title{
PENGARUH SUHU DAN LAMA PENYIMPANAN EKSTRAK BAWANG DAYAK (ELEUTHERINE AMERICANA L (MERR)) TERHADAP AKTIVITAS ANTIBAKTERI
}

\author{
Yulita Seja*, Mirhansyah Ardana, Fika Aryati \\ Laboratorium Penelitian dan Pengembangan Kefarmasian "Farmaka Tropis", \\ Fakultas Farmasi, Universitas Mulawarman, Samarinda, Indonesia \\ *Email: Yulita.seja@gmail.com
}

\begin{abstract}
Dayak Onion (Eleutherine Americana) is a typical Kalimantan plant originating from Tropical America which is used empirically as an antibacterial. And the ability of plants as an antibacterial is related to the stability of these plants. This study aimed to determine the yield, the effect of storage conditions and storage time of extracts on Staphylococcus aureus and Escherichia coli bacteria. Methods include determination of yield, phytochemical screening test, stability testing and antibacterial activity test with a concentration of $0.08 \%, 1 \%$ and $12 \%$ using the well method. Stability testing was carried out at the temperature of the refrigerator and room temperature and then observed and tested the levels of total flavonoids and antibacterial activity on days $0,3,7$. The results of this study resulted in $7.85 \%$ yield of dayak onion extract, and effective antibacterial extract activity at a concentration of $1 \%$.
\end{abstract}

Keywords: Dayak Onion, Antibacterial Activity, Stability, Storage Temperature

\begin{abstract}
ABSTRAK
Bawang Dayak ( Eleutherine Americana) merupakan tanaman khas Kalimantan yang berasal dari Amerika Tropik yang digunakan secara empiris sebagai antibakteri. Dan kemampuan tumbuhan sebagai antibakteri berhubungan dengan stabilitas tanaman tersebut. Penelitian ini bertujuan untuk mengetahui rendemen, pengaruh kondisi penyimpanan dan lama penyimpanan ekstrak terhadap bakteri Staphylococcus aureus dan Escherichia coli. Metode meliputi penentuan rendemen, uji skrining fitokimia, pengujian stabilitas serta uji aktivitas antibakteri dengan konsentrasi 0,08\%, $1 \%$ dan $12 \%$ menggunakan metode sumuran. Pengujian stabilitas dilakukan pada suhu kulkas dan suhu kamar lalu dilakukan pengamatan dan pengujian kadar flavonoid total dan aktivitas antibakteri pada hari ke $0,3,7$. Hasil penelitian ini menghasilkan rendemen ekstrak bawang dayak sebesar 7,85\%, dan aktivitas ekstrak antibakteri yang efektif pada konsentrasi $1 \%$.
\end{abstract}

Kata kunci : Bawang Dayak, Aktivitas antibakteri, Stabilitas, Suhu Penyimpanan

DOI: https://doi.org/10.25026/mpc.v8i1.317 


\section{PENDAHULUAN}

Bawang dayak mengandung senyawa kimia seperti alkaloid, glikosid, flavonoid, fenolik, steroid, dan tannin sebagai sumber potensial sebagai bahan obat. Selain itu senyawa kimia diatas pun berkhasiat sebagai antimikroba seperti alkaloid, flavonoid, tanin dan saponin (Siwi, 2010). Bawang dayak mengandung minyak atsiri yang di dalamnya terdapat kandungan flavonoid. Flavonoid termasuk senyawa fenolik alam yang berpotensial sebagai antijamur dan antibakter (Amwaalun, 2014).

Secara empiris bawang dayak sudah dipergunakan masyarakat lokal sebagai obat berbagai jenis penyakit kanker payudara, hipertensi, kencing manis (diabetes mellitus), menurunkan kolesterol, obat jerawat dan bisul, kanker usus serta untuk mencegah stroke (Galingging, 2009); penyakit weil, disentri, disuria, dan radang usus (Nawawi, 2010).

Ekstrak umbi bawang dayak (Eleutherine Americana L) memiliki efektivitas dalam penghambatan terhadap bakteri. Dimana semakin tinggi konsentrasi yang digunakan, maka kemampuan menghambat pertumbuhan bakteri semakin kuat, hal ini disebabkan karena jumlah zat antibakteri yang ada terkandung pada setiap peningkatan konsentrasi tersebut akan semakin besar (Poeloengan, Susan dan Andriani, 2005). Namun, pembuatan ekstrak umbi bawang dayak membutuhkan waktu yang cukup lama seperti halnya pada ekstrak bawang dayak yang biasa digunakan pada laboratorium untuk keperluan penelitian yang disimpan dalam jangka waktu yang cukup lama bahkan hingga berbulanbulan sehingga penggunaan ekstrak umbi bawang dayak tersebut kurang praktis dan dikhawatirkan mengalami penurunan aktivitas. Berdasarkan uraian tersebut maka dilakukan penelitian untuk mengetahui suhu dan lama penyimpanan yang optimal untuk tetap menjaga kualitas dari ekstrak umbi bawang dayak sebagai antibakteri.

\section{METODE PENELITIAN}

\section{Bahan}

Umbi bawang dayak (Eleutherine Americana L), etanol 96\%, aquades, Bakteri escherichia coli, Staphylococcus aureus, fecl3 1\%, Natrium asetat, $\mathrm{HCl}$ pekat, Logam magnesium dan $\mathrm{HCl}$, Nutrient Agar, $\mathrm{NaCl}$ 0,9\%, Sampel yang diambil di Desa

\begin{abstract}
Alat
Alat yang digunakan da;am penelitian adalah autoklaf, batang pengaduk, cawan petri, cawan porselen, gelas kimia, gelas ukur, hot plate, inkubator, kaca arloji, kertas timbang, labu erlenmeyer, labu ukur, Laminar air flow, Mangkok kaca, Mikrometer sekrup, mikropipet, ose bulat, spoit, botol vial, pinset, tabung reaksi, spektrofotometer, kuvet.
\end{abstract}

\section{Pembuatan ekstrak}

Simplisia umbi bawang dayak sebanyak 1790 gram dilakukan proses maserasi dengan pelarut etanol $96 \%$ selama 3x24 jam. Ekstrak yang diperoleh lalu dipekatkan menggunakan rotary evaporator lalu diuapkan di atas waterbath untuk memperoleh ekstrak kental. Dan dilakukan perhitungan rendemen. Hasil ekstrak kemudian dimasukan ke dalam botol vial dan dibagi menjadi 14 botol vial lalu disimpan di suhu ruang dan suhu kulkas. Kemudian dilakukan pengujian pada tiap sampling. 


\section{Skrining Fitokimia}

Uji alkaloid

Ekstrak bawang dayak ditambahkan $2 \mathrm{~mL} \mathrm{HCl}$ lalu dibagi menjadi 3 tabung reaksi dan masingmasing tabung reaksi ditambahkan pereaksi mayer, wagner dan dragendorf sebanyak 3 tetes.

Uji Flavonoid

Ekstrak ditambahkan 0,2 g serbuk $\mathrm{Mg}$, kemudian ditambahkan $5 \mathrm{~mL} \mathrm{HCl}$ pekat. Bila terbentuk warna merah, jingga atau kuning memberikan indikasi flavonoid.

\section{Uji Triterpenoid}

Ekstrak ditambahkan $2 \mathrm{~mL}$ kloroform, 2 tetes asam asetat glasial, 2 tetes $\mathrm{H} 2 \mathrm{SO} 4$. Bila terbentuk warna biru tua atau hijau kehitaman memberikan indikasi triterpenoid.

Uji Tanin

Ekstrak ditambahkan $\mathrm{FeCl} 3$ 1\% sebanyak $5 \mathrm{~mL}$ lalu dikocok. Bila terbentuk warna biru tua atau hitam selama 1 menit memberikan indikasi tanin.

\section{Uji Saponin}

Ekstrak ditambahkan $10 \mathrm{~mL}$ air panas lalu dikocok selama 1 menit diamati adanya busa kemudian ditambahkan $\mathrm{HCl} 2 \mathrm{~N}$ amati hingga 5 menit. Indikasi Saponin ditandai dengan busa yang konstan bertahan selama 5 menit setelah penambahan $\mathrm{HCl} 2 \mathrm{~N}$.

\section{Uji Pendahuluan Aktivitas Antibakteri}

Ekstrak umbi bawang dayak dibagi menjadi 3 konsentrasi yakni $0,08 \% ; 1 \%$; dan $12 \%$. lalu dilakukan pengujian aktivitas antibakteri untuk mengetahui konsentrasi efektif terbaik yang digunakan.

\section{Stabilitas Terhadap suhu dan lama penyimpanan}

Ekstrak diambil lalu disimpan di tempat dengan dua variasi suhu yaitu pada suhu kulkas dan suhu ruang selama 7 hari lalu diuji aktivitas antibakteri dan kadar flavonoid total pada hari ke 0, 3, dan 7 .

\section{Uji Aktivitas Antibakteri}

Ekstrak dengan konsentrasi 1\% diuji aktivitas antibakterinya terhadap bakteri Escherichia coli dan Staphylococcus aureus dengan metode difusi agar perforasi, teknik lubang sumuran. Kemudian diameter yang terbentuk diukur menggunakan mikrometer sekrup.

\section{Uji Kadar Flavonoid Total}

Penetapan kadar flavonoid ekstrak etanol umbi bawang dayak dengan pengukuran absorbansi secara spektrofotometri UV-Vis. Penentuan kadar flavonoid total menggunakan baku kuersetin dan pereaksi AlCl3, Natrium Asetat, dan aquadest (Amalina,2015)

\section{HASIL DAN PEMBAHASAN}

Ekstrak kental etanol umbi bawang dayak yang diperoleh sebanyak 220,3 gram dari 2805 gram simplisia kering dengan nilai rendemen $7,85 \%$. Skrining fitokimia dilakukan pada ekstrak. Hasil penapisan fitokimia yang diperoleh dapat dilihat pada tabel 1.

Tabel 1. Hasil Penapisan Fitokimia

\begin{tabular}{ll}
\hline Identifikasi & Hasil \\
\hline Alkaloid & $(-)$ \\
Flavonoid & $(+)$ \\
Tanin & $(+)$ \\
Saponin & $(+)$ \\
Triterpenoid & $(-)$ \\
\hline
\end{tabular}

Keterangan :

(+) :adanya komponen zat yang diidentifikasi

(-) :tidak adanya komponen zat yang teridentifikasi 
Hasil penapisan fitokimia pada ekstrak bawang dayak menunjukkan bahwa terdapat beberapa senyawa sekunder pada tanaman. Data tersebut memberikan bukti bahwa umbi bawang dayak memilki aktivitas biologi khususnya sebagai antibakteri, yaitu seperti flavonoid, tanin ataupun saponin .

Uji pendahuluan yang dilakukan pada ekstrak bawang dayak menggunakan 3 konsentrasi yaitu $0,08 \%$; $1 \%$; dan $12 \%$ untuk mengetahui dan menentukan konsentrasi terbaik yang digunakan sebagai antibakteri. . Dan dari hasil yang diperoleh pada pengujian ini bahwa pada konsentrasi $1 \%$ telah menunjukkan nilai konsentrasi hambat minimum (KHM) yang cukup baik dan memiliki perbedaan yang cukup siginifikan dengan konsentrasi $12 \%$ dan $0,08 \%$.

Hasil pengujian tersebut menunjukkan bahwa pada konsentrsi Konsentrasi $0,008 \%$ tidak terdapat zona bening, maka digunakan konsentrasi $1 \%$ sebagai konsentrasi terbaik untuk aktivitas antibakteri, dimana pada konsentrasi $1 \%$ dan $12 \%$ menunjukkan kemampuan untuk membunuh bakteri yang cukup signifikan dan tidak jauh berbeda dimana pada konsentrasi $1 \%$ menunjukkan konsentrasi hambat minimum yang lebih baik. Karena pada konsentrasi bahan uji terkecil tetapi mampu untuk memberikan aktivitas penghambatan pada bakteri. Oleh karena itu konsentrasi $1 \%$ digunakan sebagai konsentrasi uj yang terbaik.

Pengujian aktivitas antimikroba terhadap bakteri Escherichia coli dan Staphylococcus aureus menunjukkan respon hambatan pertumbuhan yang kuat, namun terjadi penurunan aktivitas selama proses penyimpanan dengan suhu yang berbeda, tempat penyimpanan serta lama waktu penyimpanan yang berbeda pula. Diameter zona hambat bakteri Staphylococcus aureus menunjukkan penurunan pada hari ke-3 dan hari ke-7, namun penyimpanan pada suhu ruang dan suhu refrigerator tidak menunjukkan perubahan cukup jauh karena nilai diameter hambatnya bernilai hampir sama dan tidak terlalu jauh perbedaan.

Tabel 2. Diameter Zona hambat Bakteri Staphylococcus aureus

\begin{tabular}{lcc}
\hline \multirow{2}{*}{ Perlakuan } & \multicolumn{2}{c}{ Diameter zona bening $(\mathrm{mm})$} \\
\cline { 2 - 3 } & Suhu Ruang & Suhu Refrigerator \\
\hline Hari ke -0 & 15.512 & 15.512 \\
Hari ke -3 & 14.346 & 14.779 \\
Hari ke -7 & 11.696 & 11.250 \\
\hline
\end{tabular}

Tabel 3. Diameter zona hambat Bakteri Escherichia coli

\begin{tabular}{ccccc}
\hline \multirow{2}{*}{ Perlakuan } & \multicolumn{2}{c}{ Diameter zona bening $(\mathrm{mm})$} & \multicolumn{2}{c}{ Diameter zona hambat $(\mathrm{mm})$} \\
\cline { 2 - 5 } & Suhu Ruang & Suhu Refrigerator & Suhu Ruang & Suhu Refrigerator \\
\hline Hari ke -0 & 15.938 & 15.938 & $(-)$ & $(-)$ \\
Hari ke -3 & 15.255 & 15.034 & $(-)$ & $(-)$ \\
Hari ke -7 & $(-)$ & $(-)$ & 16.807 & 17.849 \\
\hline
\end{tabular}


Diameter zona bening dan zona hambat yang terbentuk dipengaruhi oleh beberapa faktor seperti faktor lamanya waktu serta suhu penyimpanan ekstrak umbi bawang dayak, dimana semakin lama ekstrak tersebut disimpan maka zona bening yang dihasilkan semakin kecil. Zona hambat yang terbentuk tersebut disebabkan oleh zat antibakteri yang terekstrak. Seperti yang diketahui bahwa umbi bawang dayak mengandung senyawa antibakteri seperti flavonoid, tanin, saponin, alkaloid, serta senyawa fenolik. Pengujian ini berfokus pada senyawa antibakteri yang terdapat pada umbi bawang dayak yaitu flavonoid yang memiliki mekanisme kerja dengan merusak dinding sel bakteri yang terdiri dari lipid dan asam amino lalu bereaksi dengan gugus alkohol dari senyawa flavonoid sehingga dinding sel akan rusak dan menyebabkan senyawa tersebut dapat masuk ke dalam inti sel bakteri. Selanjutnya senyawa ini akan bereaksi dengan DNA pada inti sel bakteri melalui perbedaan kepolaran antara lipid penyusun DNA dengan gugus alkohol pada senyawa flavonoid akan terjadi reaksi sehingga inti sel bakteri akan mengalami lisis.

Hasil penelitian pada tabel 2 dan 3 menunjukkan bahwa ekstrak bawang dayak dapat menghambat bakteri Escherichia coli dan Staphylococcus aureus. Dapat dilihat bahwa zona bening penyimpanan pada suhu ruang dan suhu refrigerator menunjukkan bahwa pada hari ke-3 telah terjadi penurunan aktivitas antibakteri. Pada suhu ruang penurunan aktivitas yang terjadi cukup spesifik terlihat dengan rentang jarak yang cukup jauh sedangkan pada suhu refrigerator penurunan aktivitas yang terlihat tidak terlalu jauh rentangnya dan tidak terlalu spesifik. Namun perbedaan penyimpanan pada suhu ruang maupun suhu refrigerator tidak memberikan pengaruh yang cukup besar karena perbedaan rentang diameter yang tidak terlalu jauh.
Penyimpanan ekstrak umbi bawang dayak pada hari ke-3 telah mengalami penurunan aktivitas daya hambat. Hal ini dikarenakan bahwa pengaruh lama simpan ekstrak umbi bawang dayak karena semakin menurunnya kemampuan daya hambat pertumbuhan bakteri. Semakin lama penyimpanan akan semakin banyak meningkatnya aktivitas mikroorganisme yang pada akhirnya mengakibatkan terjadinya pembusukan (Suradi,2012).

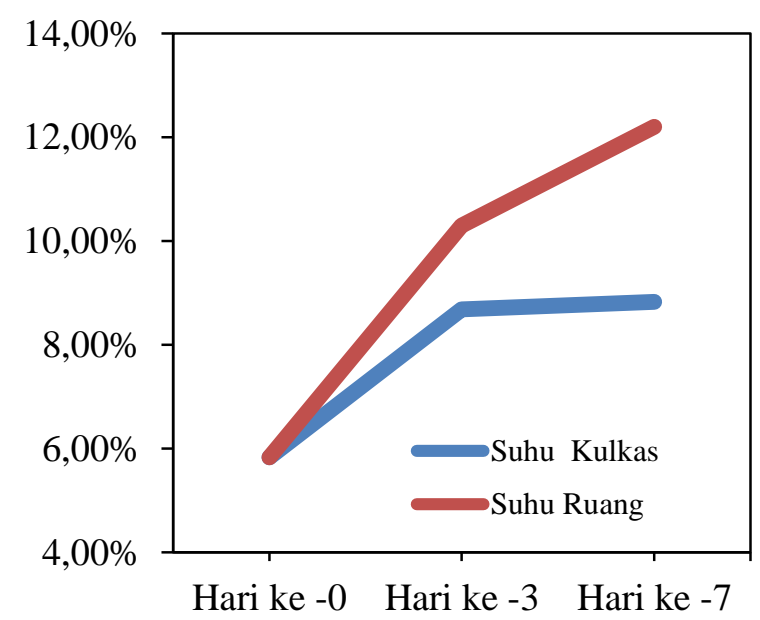

Gambar 1 : Kadar flavonoid total

Gambar 1 menunjukkan bahwa Perhitungan kadar total flavonoid dan perhitungan zona hambat ekstrak umbi bawang dayak terhadap bakteri Escherichia coli dan Staphylococcus aureus menunjukan bahwa semakin tinggi konsentrasi ekstrak umbi bawang dayak maka kadar total flavonoid juga semakin tinggi dimana konsentrasi yang digunakan dalam pengujian yaitu sebesar 2000 ppm. Hal ini berbanding terbalik dengan aktivitas antibakteri yang semakin lama semakin menurun sedangkan kadar total flavonoid semakin meningkat hal ini juga dapat disebabkan karena bebrapa faktor seperti kesterilan bahan yang dijadikan ekstrak ataupun kesegaran serta tak diketahuinya umur panen sehingga 
mengakibatkan rendahnya zona hambat dan meningkatnya kadar flavonoid total karena dapat juga disebabkan oleh senyawa yang terkandung dalam umbi bawang dayak yg memiliki aktivitas antibakteri ternyata tidah hanya flavonoid saja tapi jga senyawa lain seperti tanin, ataupun alkaloid. Maka dapat dikatakan bahwa untuk aktivitas antibakteri ekstrak umbi bawang dayak dan kadar total flavonoid tidak berkaitan karena berbanding terbalik antara keduanya. Aktivitas antibakteri dan kadar total flavonoid tidak saling mempengaruhi.

\section{KESIMPULAN}

Hasil penelitian menunjukkan bahwa ekstrak etanol umbi bawang dayak dapat menghambat aktivitas bakteri dengan KHM 1\% untuk bakteri Escherichia coli dan Staphylococcus aureus. Suhu penyimpanan dan lama penyimpanan ekstrak umbi bawang dayak (Eleutherine americana) berpengaruh terhadap daya hambat bakteri dan kadar flavonoid total.

\section{DAFTAR PUSTAKA}

[1] Armanda, Ferdio., M. Yanwar., Lia, Yulia. 2017. Efektivitas Daya Hambat Bakteri Ekstrak bawang Dayak Terstandarisasi Falvonoid Terhadap Entherococcuc faecalis (In Vitro).

[2] Depkes RI. 1986. Materia Medika Indonesia Jilid ke V. Jakarta: Ditjen POM.

[3] Depkes RI. 1986. Materia Medika Indonesia Jilid ke VI. Jakarta: Ditjen POM.

[4] Galingging RY. 2009. Bawang Dayak sebagai tanaman Obat Multifungsi. Pontianak : BPTP Kalimantan Tengah. Halaman: 9-12
[5] Nawawi A., Rachmawati W., dan Aryadi, A. 2010. Isolasi dan Identifikasi Senyawa Kuinon dari Simplisia Umbi Bawang Sabrang (Eleutherine americana Merr.). Diambil dari: www.bawang\%20tiwai/penelitianobat-bahanalamaper\%20mahasiswa\%20ITB.html.

[6] Puspadewi, Ririn., Putranti Adirestuti., Rizka Menawati. Khasiat Umbi Bawang Dayak (Eleutherine palmifolia (L) Merr.) Sebagai Herbal Antimikroba Kulit. Kartika Jurnal Ilmiah Farmasi. ISSN 2354-6565.

[7] Safaryani, N., S. haryanti dan E. D. Hastuti. 2007. Pengaruh Suhu dan Lama Penyimpanan Terhadap Penurunan Kadar Vitamin C Brokoli (Brassica oleraceae L). Buletin Anatomi Dan Fisiologi 12(2):39-45

[8] Sugiri, Y.D dan A. Anri. 2010. Prevalensi Patogen Penyebab Mastitis Subklinis (Staphylococcus aureus dan Streptococcus agalactiae) dan patogen Penyebab Mastitis Subklinis Lainnya pada Peternak Skala Kecil dan Menengah di Beberapa Sentra Peternakan Sapi Perah di Pulai Jawa. Balai Pengujian dan Penyidikan Penyakit Hewan dan Kesmavet (BP3HK) Cikole Lembang Kab. Bandung Barat, Jawa Barat, Indonesia.

[9] Syamsul E.S., Supomo., Heri Wijaya., Bramantyo A.N. 2015. Ethanolic Extract Formulation of Bawang Tiwai (Eleutherine americana) In Antiacne Cream.

[10] Suradi, K. 2012. Pengaruh Lama Penyimpanan pada Suhu Ruang terhadap Perubahan Nilai $\mathrm{Ph}$, TVB dan Total Bakteri Daging Kerbau. Jurnal Ilmu Ternak. 12(2):9-12. 